American Journal of Biomedical and Life Sciences
2016; 4(6): $81-86$
http://www.sciencepublishinggroup.com/j/ajbls
doi: 10.11648 /j.ajbls.20160406.11
ISSN: $2330-8818$ (Print); ISSN: $2330-880 \mathrm{X}$ (Online)

\title{
Microbiological Analysis of Hemodialysis Water at the University Teaching Hospital of Yaounde, Cameroon
}

\author{
Cédric Gueguim ${ }^{1}$, Nnanga Nga ${ }^{2,3}$, François Kaze Folefack ${ }^{2}$, Alain Ragon ${ }^{4}$, \\ Hortense Gonsu Kamga ${ }^{2,5}$ \\ ${ }^{1}$ Departement of Biochemistry, University of Yaounde I, Central Region, Cameroon \\ ${ }^{2}$ Faculty of Medicine and Biomedical Sciences, University of Yaounde I, Central Region, Cameroon \\ ${ }^{3}$ Institute for Medical Research and Medicinal Plants (IMPM), Yaoundé, Cameroon \\ ${ }^{4}$ Division of Uro-Nephrology Laboratory, Hospital of Conception, Marseille, France \\ ${ }^{5}$ Microbiology Laboratory of the Hospital Center and the University Hospital of Yaoundé, Central Region, Cameroon
}

Email address:

guecedricfr@yahoo.fr (C. Gueguim)

\section{To cite this article:}

Cédric Gueguim, Nnanga Nga, François Kaze Folefack, Alain Ragon, Hortense Gonsu Kamga. Microbiological Analysis of Hemodialysis Water at the University Teaching Hospital of Yaounde, Cameroon. American Journal of Biomedical and Life Sciences.

Vol. 4, No. 6, 2016, pp. 81-86. doi: 10.11648/j.ajbls.20160406.11

Received: September 23, 2016; Accepted: November 5, 2016; Published: December 8, 2016

\begin{abstract}
Rigorous control of the microbiological quality of water in hemodialysis services is important because the immune system of patients with chronic renal failure is weakened. The objective of this study was to determine the microbiological quality of water for hemodialysis in the hemodialysis department of the University Teaching Hospital of Yaoundé in order to improve the disinfection strategy. Twelve water samples were collected each month at different sites of the hemodialysis circuits A (inlet of filters), B (Outlet of filters / inlet of Reverse Osmosis (RO) device) and C (outlet of the RO device / close to the generator) between July and October 2015 to be analyzed. The bacteria were isolated after filtration of 100 $\mathrm{ml}$ of water at each site through nitrocellulose membrane with $0.45 \mu \mathrm{m}$ microporosity deposited on the surface of the Tryptone Glucose Extract Agar (TGEA) and then incubated at room temperature $\left(20\right.$ to $\left.22^{\circ} \mathrm{C}\right)$ for 7 days. After transplanting to different environments, pure bacterial isolates were identified by their cultural characters and marketed biochemical galleries. The colony count was well above the required international standards $(>100 \mathrm{CFU} / \mathrm{ml})$, for the hemodialysis water with a percentage of $83.3 \%(10 / 12)$ of non-compliance. Among the bacteria identified, nine (09) were Gram-negative bacilli including Pasteurella haemolytica, Pseudomonas fluorescens, Pseudomonas paucimobilis, Aeromonas salmonicida and Klebsiella pneumoniae subsp ozaenae, three (03) Gram-positive bacilli all Bacillus sp and six (06) Gram-positive cocci all of coagulase-negative staphylococci. The most frequently isolated bacterial genera were Pseudomonas (30.4\%), Staphylococcus (26.1\%), Aeromonas (13\%), Bacillus (13\%), Klebsiella (13\%) and Pasteurella (4.3\%). In this study, the high bacteriological contamination of the hemodialysis water with the detection of a variety of bacteria shows that the disinfection procedure of the distribution loop is not efficient and cannot prevent the development of a biofilm. A higher frequency of disinfection (almost every week), an increase of the concentration and time of contact of the chlorine disinfection product or the use of peracetic acid and a regular monitoring can contribute to improve the quality of the hemodialysis water at the CHUY to ensure a better quality of life for patients undergoing this treatment.
\end{abstract}

Keywords: Water, Hemodialysis, Microbiology, Contamination, Disinfection

\section{Introduction}

Water is the main component of the human body and, no doubt, of all living organisms. However, various microorganisms present in water can cause diseases in humans, which lead to infectious, toxigenic and parasitic processes [1]. Given the environmental degradation caused by the high rate of pollution linked to the ecological 
imbalance of the planet and the vital nature of water, the active management of the environment and the quality control of water resources are needed [2]. In the case of water contamination, the patients with chronic kidney disease are more vulnerable than the general population because of the dialysis treatment to which they are subject [1], [3]. Hemodialysis is one of the chronic renal failure treatment modalities that require pure water for the preparation of the dialysate. The blood of patients with chronic renal failure undergoing hemodialysis is exposed in contact with the dialysis membrane to about 1500 liters of water per month, thus a volume of water ranging from 18000 to 36000 liters per year [4], [5]. Patients treated for End Stage Renal Disease (ESRD) by three weekly sessions of 4 hours, are exposed in just three years of treatment to a larger volume of water that a person with normal renal function would during his entire life [6].

Urban water contains contaminants that induce proinflammatory cytokinic responses and consequently harm the health and the quality of life of the patient. It must for this purpose be treated to be suitable for the preparation of the dialysate. An impure water is unsafe to prepare dialysate; it could contain bacteria and endotoxins that are associated with acute and chronic complications of dialysis such as fever, discomfort, dialyzer clotting, nausea, migraine, amylose and the increased risk of cardiovascular disease occurrence [7], [8]. Monitoring the microbiological quality of water for hemodialysis is thus one of the main concerns of health professionals, since contamination can have serious consequences for patients.

Although microorganisms are known to grow in certain fluids associated with dialysis equipment, microbiological contamination has not been taken seriously in the developed system's projects for dialysis treatment after the death in 2013 of 11 patients at a Dialysis Center in Cameroon [9]. Gram-negative bacteria and nontuberculous mycobacteria are the most common biological contaminants from the dialysis system, the possibility of other types of contaminants such as Cyanobacteria should be kept in mind as likely to harm the health and quality of life of hemodialysis patients in Cameroon.

Based on the above considerations and taking into account the various factors that interfere with the quality of the water used in dialytic processes and potential risk factors for the health of hemodialysis patients in Cameroon, the objective of this study was to determine the bacteriological characteristics of water used for hemodialysis in the hemodialysis department of the University Teaching Hospital of Yaoundé in order to validate the efficiency of the disinfection procedure and if necessary modify the strategy of disinfection (frequency, product, concentration, time of contact) to obtain permanently a good quality of hemodialysis water.

\section{Material and Methods}

\subsection{Collection and Transport of Samples}

\subsubsection{Collection}

Samples of water collected were carried out under stringent aseptic conditions. After disinfecting the sample sites with a water-alcohol solution, we let the water run 1 to 2 minutes so that the sample is not contaminated by traces of the disinfectant, then collected in disposable sterile bottles [10].

\subsubsection{Transport}

After sampling, the bottles were clearly labeled and transported immediately to the laboratory, accompanied by a form containing all the necessary information (date, time and collection site) and rapidly analysed.

\subsection{Bacteriological Analysis}

\subsubsection{Bacteriological Isolation and Quantification}

In order to count the number of bacteria suspended in the water sample, a volume of $100 \mathrm{ml}$ water sample was filtered through a membrane with micro porosity $(0.45 \mu \mathrm{m})$. The filter was then placed on TGEA (Tryptone Glucose Extract Agar) and incubated at room temperature $\left(20\right.$ to $\left.22^{\circ} \mathrm{C}\right)$ for 7 days [10]. The numbers of colonies found were expressed as the mean of the Colony Forming Units (CFU/mL) [10]. Sterile water for Injection (SWFI) was used as control.

\subsubsection{Bacteria Identification}

After the completion of Gram staining, pure bacterial isolates were transplanted on Chapman, Mueller Hinton, MacConkey, blood and chocolate agar and incubated at $37^{\circ}$ C for 24 to 48 hours.

Bacteria Identification was carried out using commercially available biochemical galleries: API 20NE gallery for identifying bacteria classified nonfermentative, API 20E gallery for identification of enterobacteria, mannitol tests, catalase, coagulase and DNase for the identification of staphylococcal species.

\subsection{Processing and Data Analysis}

Data was collected, processed and analyzed using the Excel software (2010 version). The results were presented in tables, graphs, or narrative.

\section{Results}

\subsection{Counting the Colonies After Culture}

To see if the number of germs that may be present in the CHUY water for hemodialysis meets international standards, the colonies were counted at each sampling point and expressed in CFU / $\mathrm{mL}$. 
Table 1. Colony counts after membrane filtration

\begin{tabular}{lllll}
\hline & \multicolumn{4}{l}{ Number of colonies in CFU/ml for every collection/month } \\
\cline { 2 - 5 } & Collection 1 & Collection 2/ & Collection 3/ & Collection 4/ \\
& /July 2015 & August 2015 & September 2015 & October 2015 \\
\hline Point A & PC & PC & PC & PC \\
Point B & PC & PC* & PC & PC \\
Point C & PC & PC* & PC & PC \\
\hline
\end{tabular}

Point A = inlet of filters (systemic water); Point B = outlet of filters /inlet of RO device; Point $\mathrm{C}=$ outlet of the RO device / entry to the generator, $\mathrm{PC}=$ Presence of colonies $(>100 \mathrm{CFU} / \mathrm{mL}), \mathrm{PC}^{*}=$ Presence of colonies $(<100 \mathrm{CFU} / \mathrm{mL})$.

From Table 1, the number of colonies is far above the norm $(>100 \mathrm{UFC} / \mathrm{mL})$ for collections carried out in July, September and October for hemodialysis water. Our bacteriological results thus show the presence of a biofilm in the distribution loop because there are few differences in the number of isolated colonies between sampling points A, B and $\mathrm{C}$.

\subsection{Conformity After Culture}

From Figure 1, 83.3\% of samples were non-compliant with the number of colonies well above the norm $(>100 \mathrm{CFU} /$ $\mathrm{mL}$ ), whereas only $16.7 \%$ of samples were compliant $(<100 \mathrm{CFU} / \mathrm{mL})$.

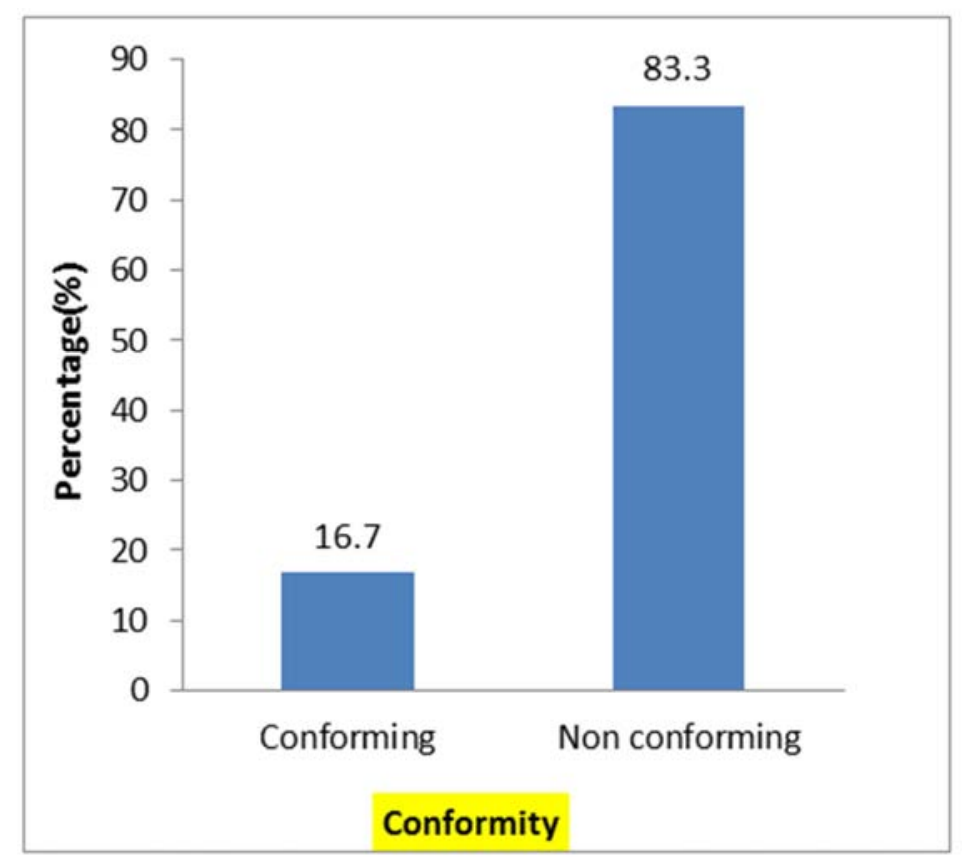

Figure 1. Percentage of conformity after culture.

\subsection{Identification of Colonies After Culture}

Gram staining was performed to determine the type of bacteria present in each sampling point. Table 2 below shows the results obtained.

It is clear from our results that the Gram-negative bacilli were more isolated, then the Gram positive cocci and finally Grampositive bacilli.

Table 2. Bacteria type as a function of each sampling point.

\begin{tabular}{|c|c|c|c|c|c|c|c|c|c|c|c|c|c|}
\hline \multirow[t]{2}{*}{ Type of Bacteria } & \multicolumn{3}{|c|}{$\begin{array}{l}\text { Collection 1/ } \\
\text { July } 2015\end{array}$} & \multicolumn{3}{|c|}{$\begin{array}{l}\text { Collection 2/ } \\
\text { August } 2015\end{array}$} & \multicolumn{3}{|c|}{$\begin{array}{l}\text { Collection 3/ } \\
\text { September } 2015\end{array}$} & \multicolumn{3}{|c|}{$\begin{array}{l}\text { Collection 4/ } \\
\text { October } 2015\end{array}$} & \multirow{2}{*}{$\begin{array}{l}\text { Total/ } \\
\text { Percentage }\end{array}$} \\
\hline & $\mathbf{A}$ & B & $\mathbf{C}$ & $\mathbf{A}$ & B & $\mathrm{C}$ & $\mathbf{A}$ & B & C & $\mathbf{A}$ & B & $\mathbf{C}$ & \\
\hline Gram - Bacilli & + & + & + & + & + & + & + & + & + & - & - & - & $9(50 \%)$ \\
\hline Gram + Bacilli & - & - & - & - & - & - & - & - & - & + & + & + & $3(16,7 \%)$ \\
\hline Gram + Cocci & - & - & - & + & + & + & - & - & + & - & + & + & $6(33,3 \%)$ \\
\hline
\end{tabular}

$(+)=$ Presence $(-)=$ Absence

\subsection{Isolated Microorganism in Water for Hemodialysis}

It is observed that the bacteria isolated vary depending on the sample. Table 3 below shows the results obtained. 
Table 3. Microorganisms species isolated in water for hemodialysis between July and October 2015.

\begin{tabular}{|c|c|c|c|c|c|c|c|c|c|c|c|c|}
\hline \multirow{2}{*}{ Isolated Bacteria } & \multicolumn{3}{|c|}{ Collectio1 July 2015} & \multicolumn{3}{|c|}{ Collection 2August 2015} & \multicolumn{3}{|c|}{ Collection 3 September2015 } & \multicolumn{3}{|c|}{ Collection 4 October 2015} \\
\hline & $\mathbf{A}$ & B & $\mathbf{C}$ & $\mathbf{A}$ & B & $\mathrm{C}$ & $\mathbf{A}$ & B & C & $\mathbf{A}$ & B & C \\
\hline Aeromonas salmonicida & - & - & - & + & + & + & - & - & - & - & - & - \\
\hline Bacillus $s p$ & - & - & - & - & - & - & - & - & - & + & + & + \\
\hline $\begin{array}{l}\text { Klebsiella pneumoniae } \\
\text { subsp Ozaenae, }\end{array}$ & + & + & + & - & - & - & - & - & - & - & - & - \\
\hline Pasteurella haemolytica & - & - & - & - & - & - & + & - & - & - & - & - \\
\hline $\begin{array}{l}\text { Pseudomonas } \\
\text { fluorescens }\end{array}$ & + & + & + & - & - & - & - & + & + & - & - & - \\
\hline $\begin{array}{l}\text { Pseudomonas } \\
\text { paucimobilis }\end{array}$ & - & - & - & - & - & - & + & + & - & - & - & - \\
\hline $\begin{array}{l}\text { Coagulase négative } \\
\text { Staphylococci }\end{array}$ & - & - & - & + & + & + & - & - & + & - & + & + \\
\hline
\end{tabular}

$(+)=$ Presence; $(-)=$ Absence; A = Inlet of filters (systemic water); B = Outlet of Filter / inlet to the RO device; $\mathrm{C}=$ outlet of the RO device / entry to the hemodialysis generator.

\subsection{Distribution of Bacterial Genera}

From Figure 2, Pseudomonas genus represented $30.4 \%$ of isolated bacteria, Staphylococcus 26.1\%, Aeromonas, Bacillus, Klebsiella and 13\% and Pasteurella 4.3\%.

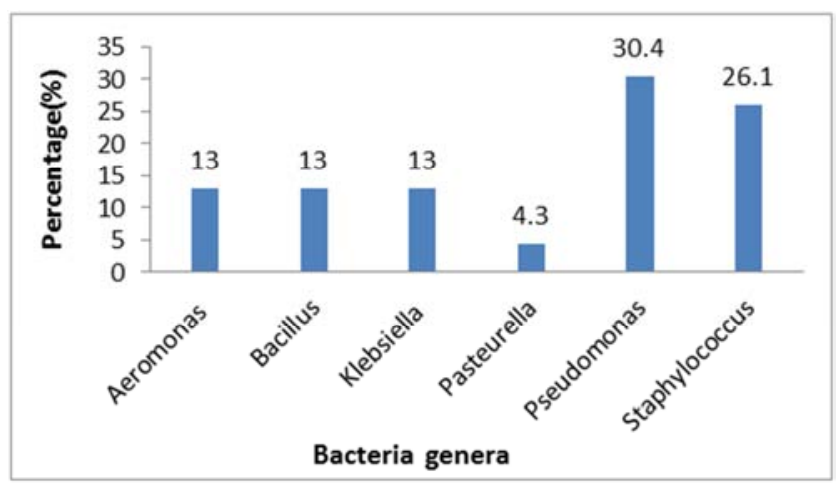

Figure 2. Isolated Bactéria as a function of genera.

\section{Discussion}

Over the past two decades, there's been considerable progress in the understanding of microbial pathogenesis in hemodialysis patients, and the current focus is on the immunity of patients, bacterial virulence and the hemodialysis treatment process [11]. It is now well established that the quality of water for hemodialysis depends on a complex chain of devices, procedures, and quality control implemented. Proper operation of the water treatment chains for hemodialysis needs preventive maintenance, periodic and regular replacement of worn or exhausted components by competent and trained personnel. Routine disinfection of reverse osmosis membranes and the water distribution system, including hemodialysis generators connected to the system should be subject to disinfection at least once a month or once a week. It is currently possible to use chemical and physical agents according to manufacturer's recommendations for a monthly disinfection of hemodialysis water treatment circuit.

In the hemodialysis center of CHUY selected for our study, disinfection of the water treatment circuit was carried out monthly with TIUTOL $K F$, an alkaline cleaning and disinfection concentrated solution composed with sodium hydroxide and hypochlorite (3.9\% of free chlorine). It is recommended to prevent biofilm and has bactericidal, fungicidal, tuberculocidal and virus inactivation properties.

Each week, patients on hemodialysis are exposed to 400 and 600 liters of water used for hemodialysis [12]. High levels of bacteria may pose a risk of bacteremia or endotoxemia to thes patients because of the possibility of bacterial passage of endotoxins through the hemodialysis membrane [13].

A variety of microorganisms can multiply rapidly in $\mathrm{HD}$ water. If the level of bacterial contamination currently exceeds the acceptable limits $(<100 \mathrm{CFU} / \mathrm{mL})$, HD patients are exposed to septicemia or endotoxemia by Gram negative bacteria.

The high bacterial load (200 to $350 \mathrm{CFU} / \mathrm{mL}$ ) detected in our study shows that it was above the international standards $(>100 \mathrm{UFC} / \mathrm{mL})$. These results are different from Montanari et al [14] performed in a hemodialysis center in the city of Sao Paulo in Brazil, with a low load (2.5 to 3.0 CFU / mL) detected bacteria. Our results, however, are similar to those of Pisani et al [3] performed in Campinas hospital in Brazil which reported a charge of $300 \mathrm{CFU} / \mathrm{mL}$ in water for $\mathrm{HD}$.

According to Ragon [6], the water distribution system for hemodialysis should be disinfected regularly (at least 1 time per month or 1 time per week) to avoid the development of a biofilm. Our results show the presence of a biofilm in the distribution circuit because there are few differences in the number of isolated colonies between sampling points A, B and C. This could reflect a weakness in the disinfection system of the distribution circuit of water for hemodialysis at CHUY.

Following the bad bacteriological results of the hemodialysis water, a new disinfection strategy is needed with the increase of the frequency and the use of a more powerfull disinfection product like peracetic acid in alternance with hypochlorite. The frequency of the disinfection process must moved from monthly to at least weekly.

Most microorganisms isolated in water for HD were Gram-negative bacilli (50\%), the Gram-positive cocci $(33.3 \%)$ and the Gram positive bacilli (16.7\%). These results are very similar to those of Rebecca [1]; Silva et al [4]; 
Santos et al [7] and Reis et al [15]. However, in the Santos et al [7] study, about $90 \%$ of the bacteria isolated were Gram negative, with a clear predominance of the genus Pseudomonas, which was able to grow rapidly, even in sterile water, reaching high concentrations $(>100000 \mathrm{CFU} /$ $\mathrm{mL}$ ) in less than 48 hours. The presence of glucose and bicarbonate in dialysis solutions, favours bacterial growth even faster and therefore a significant production of toxin causing frequent infections in hemodialysis, the leading cause of morbidity in these patients [13], [16].

The most frequently isolated bacteria in the water for hemodialysis were of the genus Pseudomonas (30.6\%), Staphylococcus (26.1\%), Aeromonas (13\%), Bacillus (13\%), Klebsiella (13\%) and Pasteurella (4.3\%). These results are similar to those of Arvanitidou et al [17] who reported a predominance of Pseudomonas (44\%) and Staphylococcus $(23 \%)$. Frequencies very different in isolation of $1.6 \%$ and $56 \%$ respectively, have both been described for the Pseudomonas genus by Pisani et al [3]. and Zunito et al [18].

Arduino [19] and Bambauer [20] studies have showed that the most commonly isolated bacteria in drinking water and water for hemodialysis were of the genus Pseudomonas. In our study, the frequency of the species Pseudomonas fluorescens 21.7\% (5/23) and Pseudomonas paucimobilis species $8.7 \%(2 / 23)$ is of concern, given the well-known resistance of Pseudomonas to biocides and antibiotics. The genus Pseudomonas is often cited as a causal agent in sepsis reports and endotoxemia [11], [19], [21].

\section{Conclusion}

Given the weakened immune system of patients with chronic renal failure, we can conclude that the detection of a variety of bacteria in the hemodialysis water in this study indicates the urgent need for regular and appropriate monitoring of water for hemodialysis by the hemodialysis center of CHUY to ensure a better quality of life for patients undergoing this treatment. There is an urgent need to modify the disinfection strategy by increasing both the frequency (almost every week), the chlorine concentration of the disinfection product and the time of contact to improve the quality of the hemodialysis water at the CHUY Center.

\section{References}

[1] Rebecca A., Curtis, J., Payne, G. (2013). Water treatment for hemodialysis: An update. Nephrology Nursing Journal, 40(5), $383-404,465$.

[2] Lima, E., Gazineu, M. H., Paiva, S. C., Rêgo, R. C., Salgueiro, A. (2003). A. Implementação do índice de qualidade de água para consumo (IQAC), na área urbana do município de Rio Formoso, PE. Higiene Alimentar. 17, 88-94.

[3] Pisani, B., Simões, M., Prandi, M., Rocha, M., Gonçalves, C., Vaz, T., et al. (2000). Surto de bacteremia por Pseudomonas aeruginosa na unidade de hemodiálise de um hospital de Campinas, São Paulo, Brasil. Revue International Adolfo Lutz. 59 (1/2), 51-56.
[4] Silva, A., Martins, C., Ferraboli, R., Jorgetti, V., Junior, R., Egidio, J. (1996). Revisão/Atualização em Diálise: Água para Hemodiálise Journal of Brasil Nefrology., 18(2), 180-188.

[5] Riela, C., (2012). Princípios de Nefrologia e Distúrbios Hidroeletrolíticos. 3rd ed. Rio de Janeiro, Guanabara Koogan, p. 607-608.

[6] Ragon, A. (2004). «l'eau et la santé dans les établissements de soins». These Edouard Kunegel, l'eau et les liquides de dialyse dans le traitement de l'insuffisance rénale chronique terminale. Soutenue publiquement le 27 juin 2013 pour obtenir le diplôme d'Etat de Docteur en pharmacie. Consulté le 3-02-2015.

[7] Brunet, P., Berland, Y. (2000). Water quality and complications of haemodialysis. Nephrology Dialysis Transplantation., 15, 578-580.

[8] Santos, F., Santos, A., Biernat, J., Souza, M., Raubach, A., Aguirre, A., et al. (2000). Detecção de endotoxina pelo teste do limulus amoebocyte lysate (LAL) em unidades de hemodiálise. Revue. Virt. Medicine. 54: 115-119.

[9] Manedong F. (2013). Insuffisance rénale: 11 malades meurent au CHU - A cause du dysfonctionnement intervenu au centre d'hémodialyse; Cameroon infos, septembre 2013. Consulté le 13-01-2015.

[10] Norme Française. (2008). Système de traitement et de distribution d'eau pour dilution des solutions concentrées pour hémodialyse - Exigences de conception, exploitation, performance et sécurité. S93-315: (2008).

[11] Jaber, B. (2005). Bacterial infections in hemodialysis patients: pathogenesis and prevention. Kidney International journal. 67: 2508-2519.

[12] Pontoriero, G., Pozzoni, P., Andrul, S., Locatelli, F. (2003). The quality of dialysis water. Nephrology Dialysis Transplantation., 18 (7): 21-25.

[13] Hoenich, A. et Ronco, C. (2007). Hemodialysis fluid: composition and clinical importance. Blood Purification journal, 25: 62-68.

[14] Montanari, B., Flávio, G., Miguel, J., Samuel, D., Regina, H., Clarice, et al. (2009). Microbiological contamination of a hemodialysis center water distribution system. Revue Internationale de Médecine tropicale. Sao. Paulo 51(1): 37-43.

[15] Reis, J., Faria, N., Filter, A. (1998). Qualidade bacteriológica da água para hemodiálise do Distrito Federal. Revue. Saúde Distrito Federal, 9 (2): 180-189.

[16] Oth, V., Jarvis, W. (2000). Outbreaks of infection and/or pyrogenic reaction in dialysis patients. Semin. Dialysis., 13: 92-96.

[17] Arvanitidou, M., Vayona, A., Spanakis, N., Tsakris, A. (2003). Occurrence and antimicrobial resistance of Gram-negative bacteria isolated in haemodialysis water and dialysate of renal units: results of a Greek multicentre study. Journal of clinical Microbiology., 95: 180-185.

[18] Zunino, P., Beltrán, L. (2002). Microbiological quality of hemodialysis water in a three-year multicenter study in Uruguay. Journal of Nephrology., 15: 374-379.

[19] Arduino, M., Bland, L. A., Agüero, S. M. (1991). Comparison of microbiologic assay methods for hemodialysis fluids. Journal of clinical Microbiology., 29: 592-594. 
[20] Bambauer, R., Schauer, M., Jung, W., Daum, V., Vienken, J. (1994). Contamination of dialysis water and dialysate. A survey of 30 centers. ASAIO Journal., 40: 1012-1016.
[21] Oie, S., Kamiya, A., Yoneda, I. (2003). Microbial contamination of dialysate and its prevention in haemodialysis units. Journal of Hospital Infection., 54: 115-119. 